\title{
Determination of Internal Pressure Value Causing Pipe Branch Model to Plastically Deform
}

Taško Maneski

Full Professo

University of Belgrade

Faculty of Mechanical Engineering

Darko Bajić

Professor

University of Montenegro

Faculty of Mechanical Engineering Montenegro

\section{Nikola Momčilović}

Assistant Professor University of Belgrade

Faculty of Mechanical Engineering

\section{Vesna Milošević Mitić}

Full Professor

University of Belgrade

Faculty of Mechanical Engineering

Martina Balać

Research Associate University of Belgrade

Faculty of Mechanical Engineering
Complexity of pressure vessels geometry usually causes stress and strain concentrations. Modern approach of stress and strain analysis involves numerical and experimental testing. Every experimental testing on the construction could endanger construction itself. Therefore, making a model of the construction has great benefits. Sub-sized model of the pipe branch of A6 third pipeline at Hydropower Plant Perućica, Nikšić was made in order to be subjected to a detailed experimental testing. The aim was to determine internal pressure value causing pipe branch model to plastically deform, and, to use these results for determining pressure causing real structure to plastically deform, without any measurements on the structure itself. Experimental measurements were carried out using strain gauge method. Strain gauges are positioned in critical zones. Numerical pipe branch model and results obtained by using finite element method (FEM) was verified with experimental results (in elasticity area). After verification in elastic area, experimentally by increasing pressure value, critical internal pressure causing plastic deformation of pipe branch model was determined. Based on the pipe branch model behaviour, and after determination of relation between the model and the real structure, maximum calculated internal pressure value to which the structure may be subjected in exploitation is assessed. Besides, weak spots on the structure were verified by obtaining the same results through experiment and calculation, which gives good guidelines for monitoring of this structure during usage, since it is possible, by using this analysis, to decrease the number of measurement locations for monitoring (in order to control exactly those measurement locations, which proved to be the most endangered).

Keywords: pipe branch model, plastic deformation, finite element method, strain gauges, stress

\section{INTRODUCTION}

Pressure vessels besides internal pressure load, may be subjected to temperature and mechanical loads [1,2]. This induces internal stresses causing failure of the structure. Stress change analysis in the vicinity of a location where two or more shells of different geometrical shapes intersect or join represents a problem many researchers deal with. Engineering way of determining stress distribution of pressure equipment subjected to different load types (internal pressure, external forces, moments) uses methods resulting from theoretical or experimental researches [3-7]. In papers $[4,5]$ authors presented results they had obtained when testing cylindrical pressure vessels subjected to different load types. Based on performed analyses, formulas for calculating stresses on cylindrical shells were obtained, and results were verified by using experimental method

Received:, October 2017, Accepted: December 2017

Correspondence to: Tasko Maneski

Faculty of Mechanical Engineering,

Kraljice Marije 16, 11120 Belgrade 35, Serbia

E-mail: tmaneski@mas.bg.ac.rs

doi:10.5937/fmet1802218M

(C) Faculty of Mechanical Engineering, Belgrade. All rights reserved involving strain gauges. Determination of pressure values causing structures to plastically deform was presented in papers [6,7]. Failures of structures usually happen because of cracks appearing on locations with the greatest stress concentration, which was also verified in papers $[8-10]$. In the area with the greatest stress concentration, a crack initiates and later propagates. By using finite element method, authors obtained pressure value leading to initial plastic deformation, which was verified experimentally; at a later stage, by increasing pressure, they also obtained critical value leading to failure $[9,10]$. Valve housing was analysed as an example of complex geometry in papers [11,12]. In their paper [11], Mitrovic et al. analysed valve subjected to different load types. Assumptions from this numerical model complied well with results obtained by using experimental method - in elasticity area. Determination of pressure value causing valve housing to plastically deform, fail or be instable while subjected to internal pressure was presented in paper [12]. Since the plastic deformation does not occur under nominal pressure required by standard, authors used dimensions of valves and certain characteristic cross-sections and numerical analysis in order to obtain 
minimum pressure value causing valve to plastically deform. Testing of bends used in control system of A6 generator in Hydropower Plant Đerdap I Kladovo was presented in paper [13]. Besides, determination of plastic loads of cracked forged piping branch junctions under internal pressure and bending moment was presented in papers $[14,15]$. Review of all experimental techniques applied in the field of pipeline integrity is shown in paper [16]. Analytical method for calculation of stress components for cylindrical shell with nozzles is shown in paper [17].

The subject of this paper is the analysis of a pipe branch model of A6 third pipeline at Hydropower Plant Perucica that is subjected to internal pressure. Experimental method with strain gauges was used for measuring stresses and determining locations with the greatest stress concentration. During FEM analysis, boundary conditions were set to be the same as in experiment, in order to compare results and verify numerical model. The model was subjected to internal pressure load that was gradually increased and internal pressure value causing pipe branch model to plastically deform was determined.

\section{BASIC MODEL}

Each structure of the vessel has perceivable locations with geometrical discontinuities where stress concentration is expected to occur. Therefore, an idea was to make a model of the given structure that would go through experimental procedure causing model to plastically deform since this was not possible to do on the real structure.

In the very beginning of model creation, it was necessary to solve the following question - what would be the appropriate relation of the pipe branch model dimensions and thickness compared to the real structure dimensions and thickness in order to realistically represent behaviour of the real structure?

As far as the model thickness and dimensions were concerned, starting formula for calculating stresses on cylindrical shells (away from stiffeners and holes) was the one defined by pressure vessel standards (boiler formula).

The pipe branch model should give the same stress values as the real pipe branch and this is ensured by using similarity method (based on boiler formula) in the following way:

$$
\sigma=\left(\frac{p \cdot R}{e}\right)_{\text {real }}=\left(\frac{\frac{p}{2} \cdot \frac{R}{5}}{\frac{e}{10}}\right)=\frac{p^{\bmod e l} \cdot R^{\bmod e l}}{e^{\bmod e l}}
$$

where $\mathrm{p}$ is internal pressure, $\mathrm{R}$ is radius of the vessel, e is thickness.

So, the pipe branch model was created with following features:

- dimensions of the model were 5 times smaller than of the real pipe branch;

- thickness: $36 \mathrm{~mm}$ was replaced with $4 \mathrm{~mm}$ (since there was no metal sheet with $3.6 \mathrm{~mm}$ thickness), which was the reason why obtained stress was $10 \%$ smaller than needed, $50 \mathrm{~mm}$ was replaced with $5 \mathrm{~mm}$ and 80 $\mathrm{mm}$ was replaced with $8 \mathrm{~mm}$;

- the pipe branch model was made of steel S355J2+N (yield point in tension $355 \mathrm{MPa}$ ) since Nioval47 (yield point in tension $470 \mathrm{MPa}$ ), used for making of the pipe branch, was not available.

All of this was taken into account later, at the time of mapping results obtained on the model onto the real pipe branch structure.

\section{EXPERIMENTAL ANALYSIS}

Experimental measurements were taken at the Laboratory for Strength of Materials at the Faculty of Mechanical Engineering in Belgrade. Strain gauges were placed on characteristic locations imposed by the model geometry. Fig. 1 shows measurement locations where stress was measured with strain gauges. For the purpose of this testing, eight strain gauges were used, as well as data acquisition system of National Instruments (NI), USA.

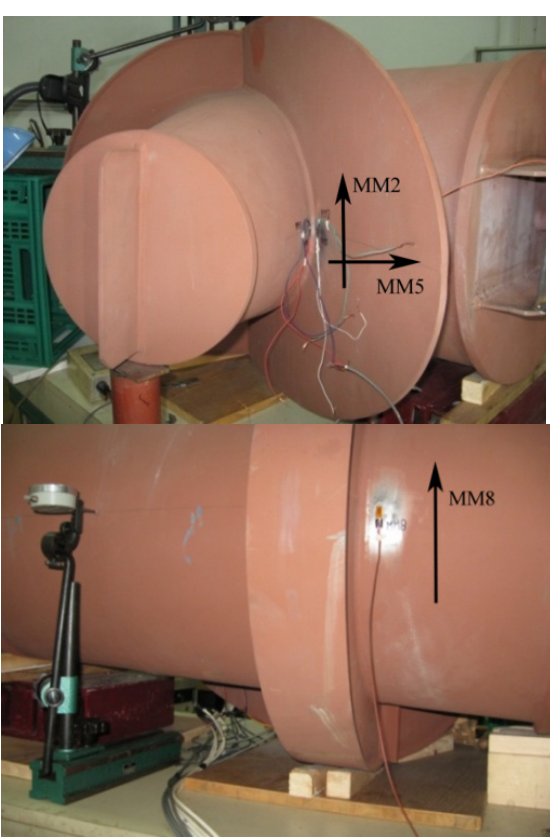

Figure 1. Measuring locations MM1 - MM8 
Figures $2-6$ show pressure-related results of measurements taken with strain gauges on all measurement locations.

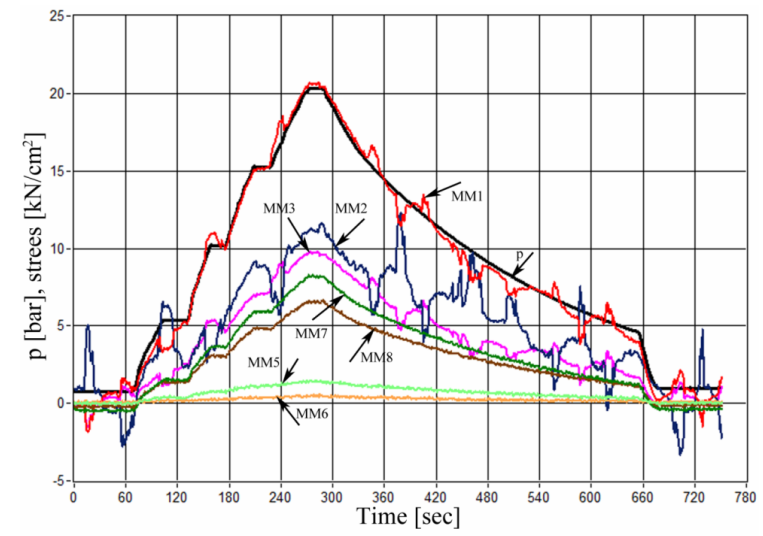

Figure 2. Measured stress as a function of pressure, for pressure values lower than 20 bar

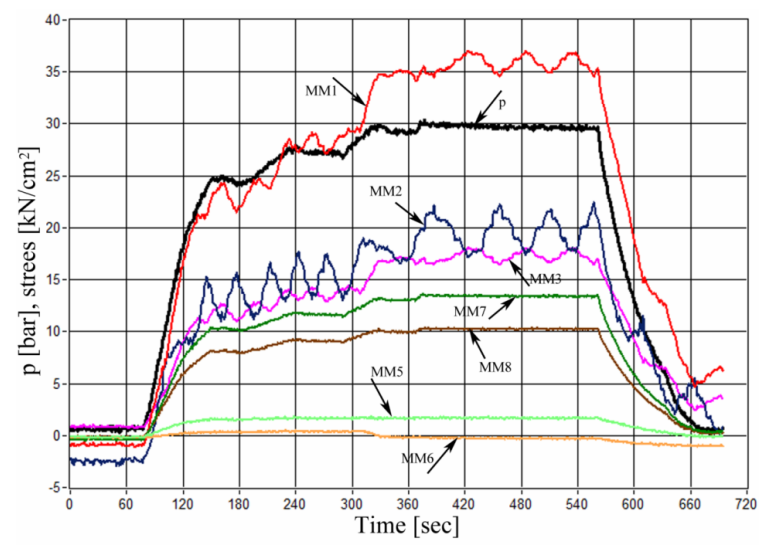

Figure 3. Measured stress as a function of pressure, for pressure value of $\mathbf{3 0}$ bar (plastic deformation occurs at MM1)

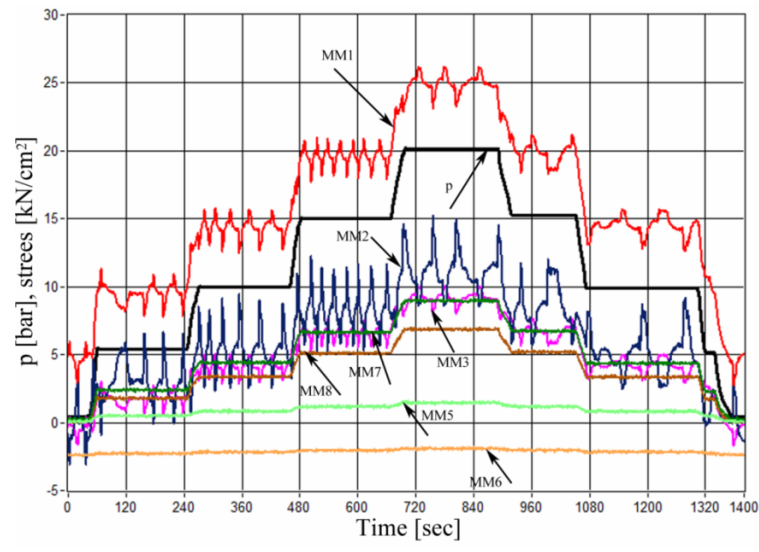

Figure 4. Measured stress as a function of pressure, after material at MM1 was plastically deformed (repeated 20 bar load, new plastic deformation does not occur)

Results of measurements are shown in Figures $2-6$. The pipe branch model was subjected to 20 bar load several times. One of the results is shown in Fig. 2, where it is clear that the model material is in elasticity area. Then, the model was subjected to 30 bar pressure load, and Fig. 3 shows that plastic deformation occurred at the MM1 measuring location when subjected to this pressure. Afterwards, 20 bar testing was repeated, and it can be seen that new plastic deformation does not occur
(Fig. 4). Figure 5 shows, under 33 bar load, new plastic deformation occurred at the same MM1 measuring location. Further increase of load resulted in new plastic deformation at MM1 location occurred, but 37 bar pressure load also resulted in plastic deformation at MM2 measuring location, which is shown in Fig. 6. Plastic deformation did not occur at any other measuring locations; because of this, for further analysis, only MM1, MM2 and MM3 will be considered. These measuring locations are as follows: MM1- circumferential direction of the cylinder with larger diameter, MM2 - vertical direction on the stiffener, on the side of the conical section of the model and MM3 - circumferential direction on the conical section of the model.

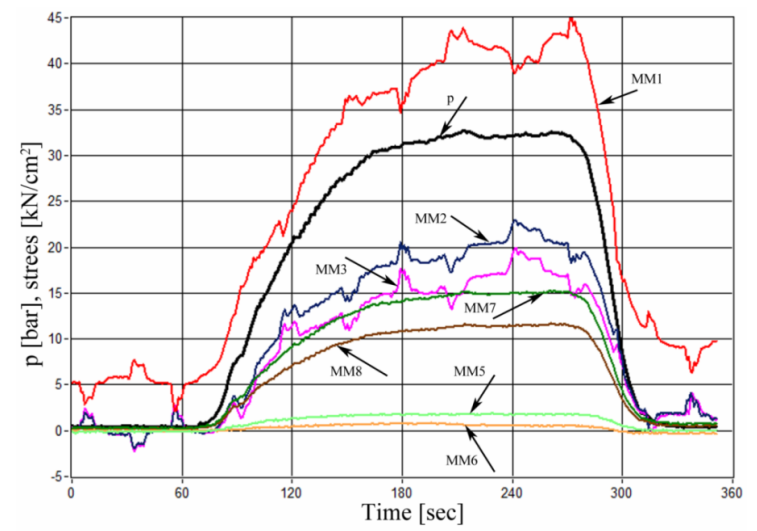

Figure 5. Measured stress as a function of pressure, after material at MM1 was plastically deformed (33 bar load, new plastic deformation occurs at MM1)

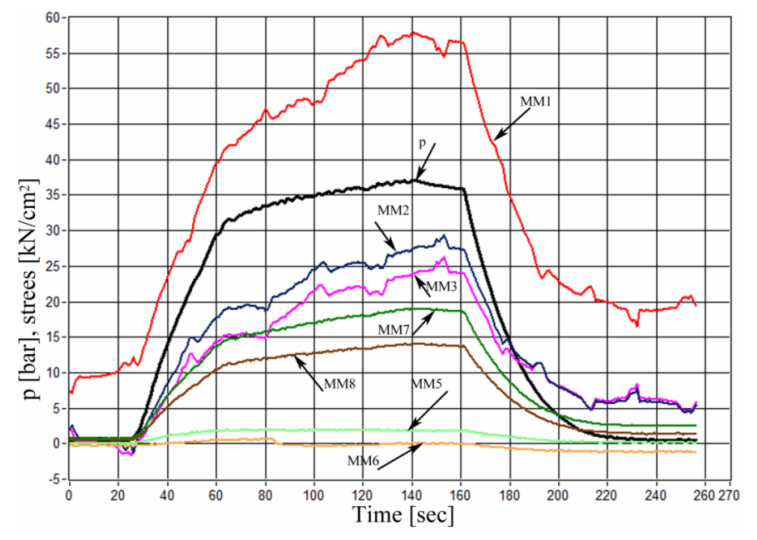

Figure 6. Measured stress as a function of pressure, for pressure value of $\mathbf{3 7}$ bar (new plastic deformation occurs at MM1 location and plastic deformation occurs at MM2 location)

\section{FINITE ELEMENT METHOD ANALYSIS}

For the purpose of strength analysis by using finite element method, a 3D model of the pipe branch was created. Figure 7 shows model geometry. Numerical model of the pipe branch was subjected to 20 bar internal pressure.

Figure 8 shows circumferential stresses of the pipe branch model at critical locations. Since this was a linear analysis of the structure (obtained stress had linear nature related to set pressure), it was possible to use scaling for obtaining results for other internal pressure values. 


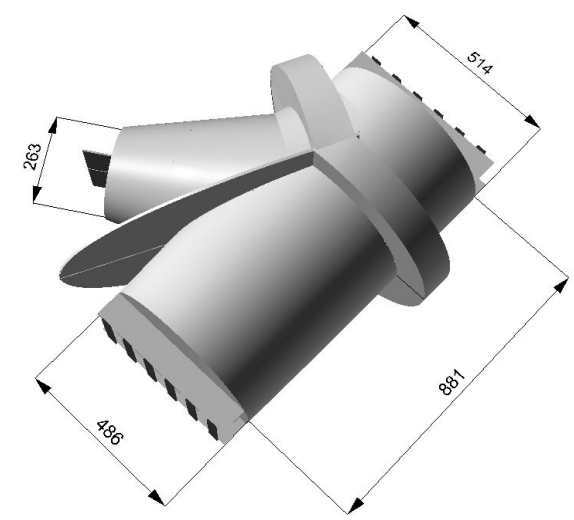

Figure 7. Geometry of the pipe branch model

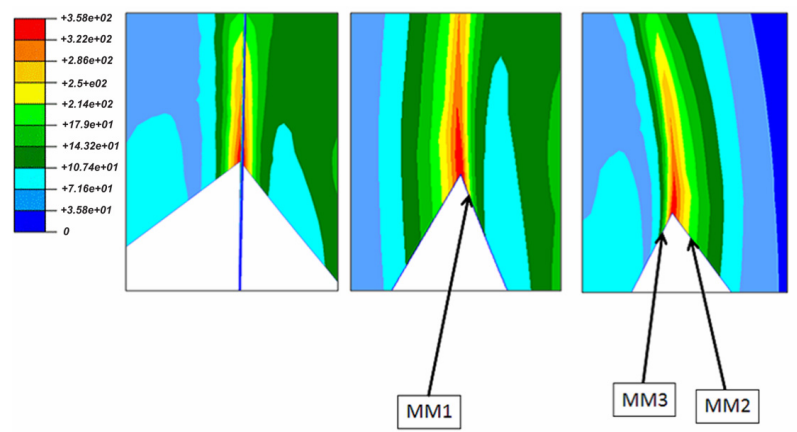

Figure 8. Stresses [MPa] in circumferential (vertical) direction at MM1, MM2 and MM3 measuring locations ( $p=20$ bar)

\section{COMPARISON OF RESULTS OBTAINED BY EXPERIMENTAL AND NUMERICAL ANALYSIS (ELASTICITY AREA)}

After analysis of obtained results, it was concluded that the greatest stress values appeared in MM1 circumferential direction, as well as at MM2 and MM3 measuring locations. Stress values at other measuring locations can be neglected since they were considerably lower than the yield point of the given material. Table 1 shows results of stress measurements taken with strain gauges and results obtained by using finite element method for 20 bar pressure.

Table 1. Comparison of results obtained by experimental measurement and numerical calculation

\begin{tabular}{|c|c|c|}
\hline \multicolumn{3}{|c|}{ Stress [MPa] } \\
\hline & Measurements (strain gauges) & FEM \\
\hline MM1 & 220 & 230 \\
\hline MM2 & 120 & 162 \\
\hline MM3 & 98 & 116 \\
\hline
\end{tabular}

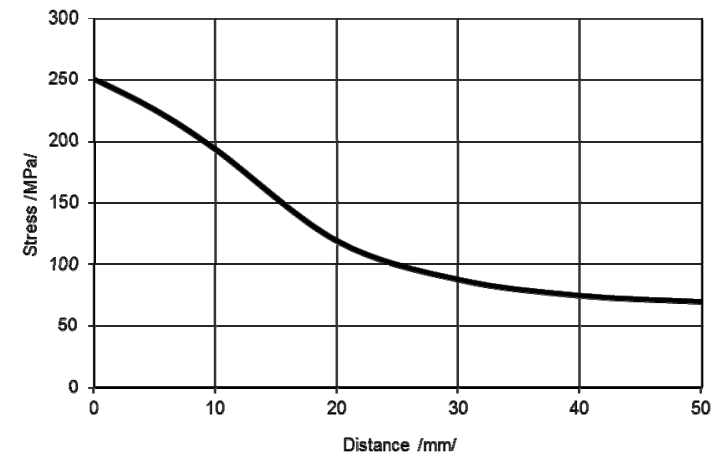

Figure 9. Stress distribution along the surface with distance $50 \mathrm{~mm}$ from critical zone at MM1
Stress distribution along the surface with distance 50 $\mathrm{mm}$ from critical zone (stress concentration area) at MM1 is shown in Fig. 9. General conclusion is that the values obtained by presented methods are very close, i.e. numerical finite element method verified experimentally obtained results.

\section{DETERMINATION OF PLASTIC DEFORMATION AND MAPPING OF MODEL RESULTS ONTO THE REAL STRUCTURE}

Figure 2 shows that all strain gauges returned to their initial states and that the pipe branch model was in elasticity area when subjected to 20 bar pressure. However, by viewing Fig. 3, it can be seen that plastic deformation of the pipe branch model occurred at MM1 location when subjected to 30 bar pressure. Figure 3 shows that stress line (strain gauge at MM1 location) did not return to 0 but to $5 \mathrm{kN} / \mathrm{cm}^{2}(50 \mathrm{MPa})$ value, which is a clear indication that plastic deformation occurred at this location when pipe branch model was subjected to internal pressure of 30 bar. Then, the pipe branch was subjected to 20 bar again, and Figure 4 shows that new plastic deformation did not occur at MM1 location (strain gauge started growing from $5 \mathrm{kN} / \mathrm{cm}^{2}$ and returned to 5 $\mathrm{kN} / \mathrm{cm}^{2}$ ). Figure 5 shows a diagram when the model was subjected to 33 bar pressure and it can be seen that strain gauge at MM1 location started growing from $5 \mathrm{kN} / \mathrm{cm}^{2}$ $(50 \mathrm{MPa})$ but then returned to $10 \mathrm{kN} / \mathrm{cm}^{2}(100 \mathrm{MPa})$ which indicates that new plastic deformation occurred at MM1. Under 37 bar (Fig. 6), plastic deformation occurred at MM1 location again, i.e. it can be seen that strain gauge at MM1 location started growing from 10 $\mathrm{kN} / \mathrm{cm}^{2}(100 \mathrm{MPa})$, but then returned to $20 \mathrm{kN} / \mathrm{cm}^{2}$ (200 $\mathrm{MPa}$ ). Also, under pressure of $37 \mathrm{bar}$, it can be seen that plastic deformation occurred at MM2 location as well.

If one gets back to similarity method, can be concluded that the pressure value causing real pipe branch A3 third pipeline at Hydropower Plant Perućica to plastically deform at MM1 location (location with the greatest stress) will be like this:

$$
\mathrm{p}=30 \cdot 0.9 \cdot \frac{47}{35.5} \cdot 2=71.5 \text { bar. }
$$

Coefficient 0.9 is ratio between thickness of real pipe branch and of pipe branch model at MM1 location $-36 \mathrm{~mm} / 40 \mathrm{~mm}$.

Ratio $470 / 355$ is the ratio between yield point in tension for real pipe branch material (NIOVAL47) and for pipe branch model material (St355J2+AR).

Coefficient 2 is coefficient of the model.

Reliability coefficient for pipe branches is $1.43=$ $\frac{71.5}{50}$

All previously mentioned means that real pipe branch should not be exposed to pressure higher than 50 bar.

Plastic deformation at other measuring locations will occur when pipe branch is subjected to much higher pressure values.

It was possible to apply similarity method to this pipe branch model subjected to internal pressure because all stresses were predominantly membrane stresses, with a very small contribution of bending stresses. 


\section{CONCLUSION}

When it is not possible to directly test real vessel structures and when non-destructive methods do not give satisfactory results of behavioural prediction of the given structure during its exploitation (and in non-standard working conditions), one of the ways for solving the problem is creation of a model of that structure and its testing. For the purpose of this paper, subsized model of the pipe branch of A6 third pipeline at Hydropower Plant Perućica was made in order to be subjected to a detailed experimental testing. Numerical calculation was performed by using finite element method. Numerical pipe branch model was verified with experimental results (in elasticity area).

The main aim was to experimentally obtain internal pressure value causing pipe branch model to plastically deform. Obtained result was mapped onto the real pipe branch structure in order to obtain maximum calculated internal pressure value to which the structure may be subjected when in exploitation. Besides, weak spots on the structure were verified by obtaining same results through experiment and calculation, which gives good guidelines for monitoring of this structure during usage, since it is possible, by using this analysis, to decrease number of measurement locations for monitoring (in order to control exactly those measurement locations, which proved to be the most endangered).

\section{REFERENCES}

[1] Živković, M., and Maneski, T.: Thermomechanical stresses of pipelines and vessels (Termomehanički naponi cevovoda i posuda), Monograph, Smeits, Beograd, 2006.

[2] Gaćeša, B., Maneski, T., Vesna M.M.: Condition and Behavior Diagnostics of Boiler Constructions, FME Trans, Vol. 40, pp. 87-92, 2012.

[3] Maneski, T.: Structure behavior analysis and diagnostics, FME Trans, Vol. 33, No. 2, pp. 89-95, 2005.

[4] Petrović, A.: Stress analysis in cylindrical pressure vessels with loads applied to the free end of a nozzle, Int. J. Pres. Ves. Pip. Vol.78, pp.485-493, 2001.

[5] Petrović, A., Balać, M., Jovović, A., and Dedic, A.: Oblique nozzle loaded by the torque moment stress state in the cylindrical shells on the pressure vessel, Proc. Inst. Mech. Eng. C J. Mech. Eng. Sci. Vol. 226, pp. $567-575,2012$.

[6] Patel, D.M., and Kumar, B., Limit load estimation of cylindrical vessel with oblique nozzle, IJERT Vol. 2, pp. 2421 - 2427, 2013.

[7] Xuan, F.Z., Li, P.N., Tu, S.T.: Limit load analysis for the piping branch junctions under in - plane moment,Int.J.Mech.Sci. Vol.48, pp. 460-467, 2006.

[8] Petrasinovic, N., Petrasinovic, D., Rasuo, B., Milkovic, D.: Aircraft Duraluminium Wing Spar Fatique Testing, FME Transactions Vol. 45, pp. 531-536, 2017.

[9] Sang, Z.F., Xue, L.P., Lin, Y.J., and Widera, G.E.O.: Limit and burst pressures for a cylindrical shell intersection with intermediate diameter ratio, Int. J. Pres. Ves. Pip, Vol. 79, pp. 341 - 349, 2002.

[10] Chapuliot, S., Moulin, D. and Plancq, D., Mechanical behavior of a branch pipe subjected to out-of-plane bending load, J. Press. Vess. T, Vol. 124, No. 1, pp. 7 - 13, 2002.

[11]Galić, I., Vučković, K., and Tonković, Z.: Nonlinear analysis of two - way glove valve housing, Tehn. vjesn, Vol. 17, pp. 67-74, 2010.

[12] Mitrović, N., Milošević, M., Momčilović, N., Petrovic, A., Sedmak, A., Maneski, T., and Zrilic, M.: Experimental and numerical analysis of local mechanical properties of globe valve housing, Chem. Listy, Vol. 106, pp. 491 - 494, 2012.

[13] Dinić, I., Arsić, M., Međo, B., Stefanović, A., Grabulov, V., and Rakin, M.: Effect of welded joints imperfection on the integrity of pipe elbows subjected to internal pressure, Tehn. Vjesn, Vol. 20, pp. 285-290, 2013.

[14] Yahiaoui, K., Moffat, D.G., and Moreton, D.N.: The collapse behaviour of a forged piping branch junction under internal pressure, Proc 9th Interantional Conference Pressure Vessel Technology, Sydney, (2000).

[15] Yahiaoui, K., Moffat, D.G., and Moreton, D.N., Plastic loads of cracked forged piping branch junctions: experimental results and comparison with numerical data, Int. J. Pres. Ves. Pip, Vol. 77, pp. 249-260, 2000.

[16]Freire, J.L.F., Vieira, R.D., Benjamin, A.C., Experimental techniques in the field of pipeline integrity, Exp. Techniques, Vol. 30, No. 4, pp. 4450, 2006.

[17] Ming-De Xue, Qing-Hai Du, Keh-Chih Hwang and Zhi-Hai Xiang: An analytical method for cylindrical shells with nozzles due to internal pressure and external loads - part I: theoretical foundation, J. Press. Vess.T. Vol. 132, No.3, pp. 031206-1 - 031206-9, 2010.

\section{ОДРЕЪИВАЊЕ ВРЕДНОСТИ УНУТРАШЫЕГ ПРИТИСКА КОЈИ ЋЕ ДОВЕСТИ ДО \\ ПЛАСТИЧНЕ ДЕФОРМАЦИЈЕ НА МОДЕЛУ РАЧВЕ}

Т. Манески, Д. Бајић, Н. Момчиловић, В. Милошевић Митић, М. Балаћ

Сложеност геометрије посуда под притиском обично представља узрок појаве концентрације напона и деформација. Савремени приступ анализе стања напона и деформација укључује нумеричка и експериментална испитивања. Свако експериментално тестирање на реалној конструкцији може угрозити саму конструкцију. Стога, прављење модела неке конструкције има велике предности. Умањени модел рачве А6 трећег цевовода на XE Перућица, Никшић је израђен како би био подвргнут детаљном експерименталном тестирању. Циљ је био да се одреди вредност унутрашњег притиска који доводи до пластичне деформације на 
моделу рачве и да се ови резултати користе за одређивање притиска који ће стварну конструкцију довести до пластичног деформисања без икаквих мерења на самој конструкцији. Експериментална мерења су спроведена методом мерних трака. Мерне траке су позициониране на критичне зоне. Нумерички модел и резултати добијени методом коначних елемената (ФЕМ) потврђени су експерименталним резултатима (у области еластичности). Након верификације у еластичној области, повећањем притиска, експериментално одређена је критична вредност унутрашњег притиска који је изазвао пластичну деформацију модела рачве. На основу понашања модела рачве и након одређивања односа између модела и стварне конструкције, процењује се максимална израчуната вредност унутрашњег притиска на коју се реална конструкција може изложити. Поред тога, слабе тачке на конструкцији су потврђене добијањем истих резултата кроз експеримент и прорачун, што даје добре смернице за праћење ове конструкције током експлоатације, с обзиром на то да је оваквом анализом могуће смањити број мерних места за праћење (у смислу да се контролишу тачно она мерна места која су се показала као најкритичнија). 